\section{Hemicholinium-3 induced amnesia: Some temporal properties*}

\author{
NEIL I. WIENER and JON MESSER \\ York University, Downsview, Ont., Canada
}

Following one-trial passive avoidance training, rats were injected via intrahippocampal cannulae with hemicholinium-3 or saline. Hemicholinium-3injected rats showed little retention 18,24 , or $30 \mathrm{~h}$ later but complete retention after $6 \mathrm{~h}, 3$ days, and 7 days.

Results of a number of recent experiments (Deutsch, Hamburg, \& Dahl, 1966; Hamburg, 1967; Deutsch, 1969; Biederman, 1970; Wiener, 1970) have been interpreted as indicating that memory involves biochemical changes that modify conduction between the members of certain cholinergic neuron pairs. Essentially this thesis argues that synaptic bombardment results in a durable morphological or biochemical change that renders a particular junction or set of junctions more susceptible to subsequent activation via the same pathway.

A number of drugs are available which affect synaptic transmission by differing modes of action, offering the possibility of interrupting the memory process in the different stages. If, indeed, learning is followed by a transient release of $\mathrm{ACh}$ which initiates a long-term change, interfering with cholinergic synthesis might not prevent the development of long-term memory but could result in temporarily rendering the memory inaccessible due to presynaptic transmitter depletion. To test this possibility, hemicholinium-3, which inhibits ACh synthesis by competing with choline for access to the enzyme cholineacetylase (Gardner, 1961), was administered following learning.

\section{EXPERIMENT 1}

Subjects

Sixty-three naive male Wistar rats, 80-100 days old, were housed singly with ad lib access to food and water. One week prior to receiving avoidance training, they were bilaterally implanted with chronic indwelling 21-gauge cannulae in the hippocampus ( $2 \mathrm{~mm}$ caudal, $2 \mathrm{~mm}$ lateral to bregma, and lowered $2 \mathrm{~mm}$ from the skull surface). The cannulae were held in place by cranioplastic cement anchored to stainless steel screws drilled into the skull.

\section{Apparatus}

The rats were trained in a metal two-compartment step-through passive

* This research was supported by Grant A0301 from the National Research Council of Canada. avoidance apparatus, similar in design to one described by Jarvik \& Kopp (1967). The outside dimensions of the compartments were $12 \times 9.5 \times 10$ in. and $12 \times 9.5 \times 8$ in. The inside walls converged toward the bottom at an angle of $60 \mathrm{deg}$, forming a trough-shaped floor which was 7 in. from the bottom drainage channel to the hinged transparent Plexiglas top in the larger compartment and 5 in. from the bottom to metal top in the smaller. The larger safe compartment was painted white and illuminated with a $30-\mathrm{W}$ bulb. The floor of the smaller compartment was made of two parallel rows of eight $1.12 \times 6.25 \mathrm{in}$. stainless steel plates which were wired to deliver a $1-\mathrm{mA}$ shock when the rat bridged the floor. The compartments were connected by a 3-in.-diam sliding door.

\section{Procedure}

On the training day, rats were put in the start compartment facing the door; after $5 \mathrm{sec}$ the door was opened. When the rat entered the dark compartment with all four feet, the timer was stopped and shock delivered until the rat returned to the light compartment and remained $120 \mathrm{sec}$. The rat was then removed, lightly anesthetized with Halothane, and injected, using a Hamilton microsyringe with a 30 -gauge needle. The injection needle penetrated $1 \mathrm{~mm}$ through a rubber seal at the cannula guide tip. Bilateral injections were each 3.5 microliters of either HC-3 solution (.4 mg total) or the physiological saline drug medium. Retention tests were carried out either $24 \mathrm{~h}$ or 7 days following training and injection, except for some control groups who were injected $24 \mathrm{~h}$ prior to training or received $\mathrm{HC}-3$ injections following training and $24 \mathrm{~h}$ prior to Day 7 retest.

\section{Results}

Results are shown in Table 1. Administration of HC-3 shortly after training produced amnesia on Day 2 but not on Day 7 (Mann-Whitney $\mathrm{U}=0, \mathrm{p} \leqslant .01$ ).

The median step-through latency for naive animals (including preinjected controls) was 10 sec. Rats injected with $\mathrm{HC}-3$ immediately after training and on Day 6 showed retention on Day 7. Histological examination failed to reveal any damage other than cannulae tracks and a small amount of damage at the cannula guide tip.

\section{EXPERIMENT 2}

The purpose of this experiment was to replicate and extend the findings of Experiment 1. Animals were tested after various retention intervals.

$$
\text { Method }
$$

The surgical and training procedures were identical to those used previously. The injection procedure was modified so Halothane anesthetization prior to injection was unnecessary. The injection cannula was connected by polyethylene tubing to a Hamilton microsyringe mounted on a modified Davis Liquid Pump (Davis Scientific Instrument Company, Model LR-131), permitting automatic injection of the proper volume of drug solution.

The Ss $(\mathrm{N}=81)$ were tested $6 \mathrm{~h}$, $18 \mathrm{~h}, 24 \mathrm{~h}, 30 \mathrm{~h}, 3$ days, or 7 days following training-injection. Saline controls were tested at $24 \mathrm{~h}$, another control group was injected with $\mathrm{HC}-3$ on Day 6 and tested on Day 7, and a final control group was injected with $\mathrm{HC}-36 \mathrm{~h}$ prior to training.

\section{Results and Discussion}

Results are shown in Table 2. Administration of $\mathrm{HC}-3$ immediately following training produced amnesia on the 18-, 24-, and 30-h tests $(\mathrm{p} \leqslant .05, .01, .001$, respectively). Complete retention was found for Ss tested $6 \mathrm{~h}, 3$ days, or 7 days following training-injection. The saline controls showed retention, as did the Day 6 $\mathrm{HC}-3$ group. Injection of $\mathrm{HC}-3$ prior to training does not affect initial step-through latency.

HC-3 interferes with choline transport, and choline is necessary for the resynthesis of acelylcholine in presynaptic terminals; therefore, $\mathrm{ACh}$ cannot be resynthesized while the drug is present (Scheuler, 1955; Birks \& MacIntosh, 1961; MacIntosh, 1961). However, neural transmission will continue for some time despite the

Table 1

Median Step-Through Latencies on the Retention Test Trials (Key, HC-3, Hemicholinium-3)

\begin{tabular}{lcc}
\hline $\begin{array}{c}\text { Drug } \\
\text { Treatment }\end{array}$ & $\begin{array}{c}\text { Reten- } \\
\text { tion } \\
\text { Day }\end{array}$ & $\begin{array}{c}\text { Median } \\
\text { Test } \\
\text { Latency } \\
\text { (Sec) }\end{array}$ \\
\hline HC-3 & 2 & 43 \\
HC-3 & 7 & $120+$ \\
HC-3(1) \& HC-3(6) & 7 & $120+$ \\
Saline & 2 & $120+$ \\
Saline & 7 & $120+$ \\
Halothane & 2 & $120+$ \\
Halothane & 7 & $120+$ \\
\hline
\end{tabular}




\begin{tabular}{lcc}
\hline Group & $\begin{array}{c}\text { Median } \\
\text { Training } \\
\text { Latency } \\
\text { (Sec) }\end{array}$ & $\begin{array}{c}\text { Median } \\
\text { Test } \\
\text { Latency } \\
\text { (Sec) }\end{array}$ \\
\hline HC-3, 6 h retention* & 4.5 & $120+$ \\
HC-3, 18 h retention* & 4.0 & 78 \\
HC-3, 24 h retention* & 8.0 & 30 \\
HC-3, 30 h retention* & 4.5 & 11 \\
HC-3, 3 day retention* & 2.5 & $120+$ \\
HC-3, 7 day retention* & 4.0 & $120+$ \\
Saline, 24 h retention* & 5.5 & $120+$ \\
HC-3, 6 h trainingt & 9.0 & \\
HC-3, Day 6 injection, & 5.0 & $120+$ \\
Day 7 retentiont & & \\
\hline
\end{tabular}

$* N=10$ per group, $+N=7$ per group

inhibition of ACh synthesis because of presynaptic ACh stores. The length of time a presynaptic ending will continue to release $\mathrm{ACh}$ varies inversely with the rate of neuron firing.

The U-shaped memory-loss function can be explained by the interaction of the drug's mode of action with hypothesized temporal changes in the memory substrate. Memory is in evidence $6 \mathrm{~h}$ following training-injection when the $\mathrm{ACh}$ stores are not yet depleted; depletion between 18 and $30 \mathrm{~h}$ results in retrieval failure, and finally by Day 3 , the drug effect has worn off. The injection on Day 6 has no effect on Day 7 , possibly because activity in the pathways involved in memory was low.

The results of this experiment and others (Erickson \& Patel, 1969) suggest that increased release of $\mathrm{ACh}$ following the learning event is the initial process facilitating or mediating the development of an enduring neural change subserving memory.

\section{REFERENCES}

BIEDERMAN, G. B. Forgetting of an operant response: Physostigmine produced increases in escape latency in rats as a function of time of injection. Quarterly Journal of Experimental Psychology, 1970, 22, 384-388.

BIRKS, R. I., \& MacINTOSH, F. C. Acetylcholine metabolism of a sympathetic ganglion. Canadian Journal of Biochemical Physiology, 1961, 39 , 787-826.

DEUTSCH, J. A. The physiological basis of memory. Annual Review of Psychology. 1969, 20, 85-104.

DEUTSCH, J. A., HAMBURG, M. D., \&
DAHL, H. Anticholinesterase induced amnesia and its temporal aspects. Science, 1966, 151, 221-223.

ERICKSON, C. H., \& PATEL, J. B. Facilitation of avoidance learning by hippocampal electrical stimulation. Journal of Comparative \& Physiological Psychology, 1969, 68, 400-406.

GARDNER, J. E. The inhibition of acetylcholine synthesis in brain by hemi cholinium. Biochemical Journal, $1961,81,297-303$

HAMBURG, M. D. Retrograde amnesia produced by intraperitoneal injection of physostigmine. Science, 1967, 156. 973-974.

JARVIK, M. E., \& KOPP, R. An improved one-trial passive avoidance learning situation. Psychological Reports, 1967, 21, 221-224.

MacINTOSH, F. C. Effect of hemicholinium-3 on acetylcholine turnover. Federation Proceedings, 1961, 20, 562-568.

SCHUELER, F. W. A new group of respiratory paralyzants: The hemicholiniums. Journal of Pharmacology \& Experimental Therapeutics, $1955,115,127-143$.

WIENER, N. I. Electroconvulsive shock induced impairment and enhancement of a learned escape response. Physiology \& Behavior, 1970, 5, 971-974.

WIENER, N. I., \& DEUTSCH, J. A. Temporal aspects of anticholinergic and anticholinesterase induced amnesia. Journal of Comparative \& Physiological Psychology, 1968, 66, 613-617. 